Florence McKenna recently retired as head of the GSPIA/economics librarian at the University of Pittsburgh Libraries.

Eleanor Pinkham retired July 31 after almost 30 years of service at Kalamazoo College (KC), Michigan. Pinkham joined KC in 1964 and was named library director in 1971. In 1982 she became director of library and media services. She also served as curator of the A.M. Todd Rare Book Room and of the college's art collection. Pinkham received the Michigan Library Consortium's Distinguished Service Award in 1982; was

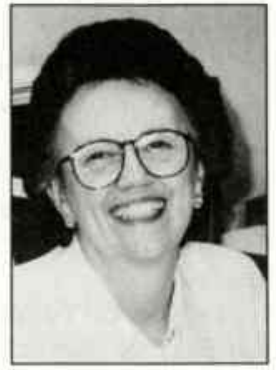

Eleanor Pinkham elected president of the Michigan Library Association in 1984; was recognized as Michigan's Librarian of the Year in 1986; and was elected chair of ACRL's College Libraries Section in 1987.

Donald L. Saporito, director of the University of Southwestern Louisiana (USL) Libraries, retired October 1, 1993. He joined USL in 1978 from Dartmouth College, where he was chief of processing and automation services. Under his leadership, the USL Libraries implemented an online integrated library automation system (DOBIS), acquired a CD-ROM network, added a third floor to the Dupre Library, and underwent an extensive library expansion project.

Dale Winkels has retired as Slavic materials cataloging librarian at the University of Pittsburgh Libraries.

\section{Advertiser index}

$\begin{array}{ll}\text { American Spectator } & 665 \\ \text { AMIGOS } & 637 \\ \text { Blackwell } & \text { cover 2 } \\ \text { Bowker/Reed } & \text { cover 4 } \\ \text { CD Plus Technologies } & 623 \\ \text { Digital Directory Assist. } & 639 \\ \text { PAIS } & 631 \\ \text { SIRS } & 640 \\ \text { University of Missouri } & 643 \\ \text { Univ. of Oklahoma } & 656 \\ \text { WLN } & \text { cover 3 }\end{array}$

Lisa Woo has retired as East Asian librarian at the University of Pittsburgh Libraries.

\section{Deaths}

Jane W. Johnson, academic librarian at Virginia Commonwealth University, Richmond, died last April at her home in Richmond. Johnson was an active member of ACRL's Education and Behavioral Sciences Section (EBSS) and its Social Work/Social Welfare Committee, and worked on the section's publications. Memorial contributions can be made to: The Cathedral of the Sacred Heart, 823 Park Ave., Richmond, vA 23220.

W. Porter Kellam, director emeritus of the University of Georgia (UG) Libraries, Athens, died on August 29. He was 87 years old. Kellam earned a bachelor's degree from Duke University in 1928, and an MLS from Emory University in 1931. He began his career as a librarian at the University of North Carolina and served as the head librarian at North Carolina State University, West Virginia University, and the University of South Carolina. Following graduate study at the University of Illinois, Kellam was appointed director of libraries at UG in 1950 and stayed in that position until his retirement in 1973. Professionally active, Kellam served as editor of Soutbeastern Librarian, and president of the Southeastern Library Association, the West Virginia Library Association, and the Georgia Library Association.

Orlin C. Spicer, former librarian at J. Sterling Morton High School and Junior College, Cicero and Berwyn, Illinois, died September 8 at the age of 83. Spicer began his career in 1942 at the University of Missouri (UM), served as librarian at Monticello College from 1943-45, and returned to UM as assistant to the librarian and head of circulation from $1945-47$. He was librarian at Illinois Wesleyan University from 1947-51, then served as librarian at Morton for 20 years. A life member of ALA, Spicer was treasurer of the Illinois Library Association and taught as a guest faculty member at the George Peabody and North Carolina Library schools. A graduate of Whitworth College, he also held degrees from Gonzaga University and George Peabody College. 